\title{
Bilateral orbital metastasis as an initial presentation of hepatocellular carcinoma
}

\author{
Kay Thi Myint ${ }^{1}$, Ko Ko Thant ${ }^{2}$, Moe Thazin ${ }^{3}$ \\ ${ }^{1}$ Faculty of Medicine, SEGi University, Sibu Clinical Campus, Sarawak, Malaysia; \\ ${ }^{2}$ Department of Ophthalmology (Retired), University of Medicine 2, Yangon, \\ Myanmar; ${ }^{3}$ Department of Ophthalmology, Hlaing Tha Yar General Hospital, \\ Yangon, Myanmar
}

\begin{abstract}
Purpose: To describe a case of biopsy-confirmed bilateral orbital metastasis of previously undiagnosed hepatocellular carcinoma, presenting with bilateral proptosis.

Case description: A 57-year-old man presented with painless bilateral proptosis over 2 months. At presentation, the best-corrected visual acuity was 20/60 in the right eye and 20/20 in the left eye. Ocular examination revealed bilateral asymmetrical non-axial proptosis with Hertel exophthalmometer reading of $24 \mathrm{~mm}$ in the right eye and $22 \mathrm{~mm}$ in the left eye. There was mild inferior displacement in both eyes. Apart from mild exposure keratopathy in the right eye, both anterior and posterior segment examinations were not remarkable. Orbital computerized tomography (CT) scan showed soft tissue masses in the superotemporal quadrants of both orbits associated with lytic bone lesions. An orbital biopsy confirmed that it was metastatic hepatocellular carcinoma (HCC). Ultrasound abdomen revealed multifocal HCC with underlying cirrhosis. We planned for further investigations such as hepatitis serology, alfa-fetoprotein, and CT abdomen, but he refused to proceed with investigations and treatment.

Conclusion: Orbital metastasis, more so as a bilateral involvement, is a rare phenomenon. It may present as an initial manifestation of undiagnosed systemic cancer. Orbital metastasis should be considered when diagnosing patients with bilateral proptosis, and orbital biopsy is crucial for histopathological diagnosis.
\end{abstract}

Keywords: bilateral proptosis, hepatocellular carcinoma, orbital metastasis, ocular oncology, ocular pathology

Correspondence: Dr. Kay Thi Myint, Faculty of Medicine, SEGi University, Sibu Clinical Campus, Sarawak, Malaysia.

E-mail: kaythimyint.eye@gmail.com 


\section{Introduction}

The orbit is an unusual site for cancer metastasis. Metastatic orbital tumors are rare conditions that account for 3-7\% of all orbital neoplasms. It occurs in $2-3 \%$ of patients with systemic cancers. ${ }^{1}$ It is more commonly associated with carcinomas of breast, lung, and prostate, and less commonly with kidney, skin, and gastrointestinal tract. Most cases present with unilateral involvement.

Hepatocellular carcinoma (HCC) is a primary malignant tumor derived from hepatocytes. It accounts for $80 \%$ of all liver cancers. It is one of the cancers with the highest mortality rates globally and the third most common cause of cancer-related deaths in the Asia-Pacific region. ${ }^{2}$ In East and Southeast Asia, it is associated with the highest incidence and mortality among both sexes. ${ }^{3}$ Men have a higher incidence, and it is more common in those aged 65 years and above. ${ }^{2}$ The most common and well-known risk factor is chronic infection with hepatitis $B$ and $C$ viruses. Other risk factors include obesity, diabetes mellitus, cirrhosis related to heavy alcohol intake, non-alcoholic fatty liver disease, smoking, and ingestion of aflatoxin..$^{2,3}$

Metastasis of HCC occurs in approximately $30-50 \%$ of patients. It primarily metastasizes to lung, bones, and lymph nodes. HCC metastasis to the orbit is a rare phenomenon, more so as a bilateral involvement and first presenting feature. There have been only a few reports of histopathologically proven orbital metastasis from HCC in the past. Almost all cases reported for orbital metastasis secondary to HCC were unilateral cases (Table 1). Herein, we report a case of biopsy-confirmed orbital metastasis of HCC in a 57-year-old man, who first presented with painless bilateral proptosis.

\section{Case report}

A 57-year-old man presented with blurred vision in the right eye for 15 days and bilateral, asymmetrical, painless, progressive proptosis of 2 months duration (Fig. 1). It involved the right eye first and then eventually the left eye, but was more severe on the right. He had no known chronic illnesses apart from a history of completed treatment for pulmonary tuberculosis 3 years prior. He denied any alarming social habits, such as smoking and excessive alcohol consumption. The best-corrected visual acuity was 20/60 in the right eye (RE) and 20/20 in the left eye (LE). Examination revealed superior sulcus fullness and bilateral proptosis with Hertel exophthalmometer readings of $24 \mathrm{~mm}$ RE and $22 \mathrm{~mm}$ LE. There was a mild inferior displacement of the globes. A solid, non-tender, immobile mass was palpable in the right superior sulcus. Ocular motility in both eyes (BE) showed limitations in upgaze. Anterior segment examination revealed conjunctival congestion and chemosis in the RE. There was mild haziness over the right inferior cornea due to exposure keratopathy. LE showed mild congestion 
Table 1. Case reports of biopsy-proven orbital metastasis from HCC in the literature to date

\begin{tabular}{|c|c|c|c|c|c|c|}
\hline & Authors & $\begin{array}{l}\text { Age } \\
\text { (years) }\end{array}$ & Sex & Presenting features & Laterality & Remark \\
\hline 1 & Lubin $(1980)^{9}$ & 69 & M & Proptosis, pain & $\mathrm{R}$ & \\
\hline 2 & Zubler $(1981)^{10}$ & 64 & M & $\begin{array}{l}\text { Mass at temporal } \\
\text { fossa, proptosis, } \\
\text { diminished vision, } \\
\text { ophthalmoplegia }\end{array}$ & L & \\
\hline 3 & $\begin{array}{l}\text { Wakisaka } \\
(1990)^{11}\end{array}$ & 58 & M & $\begin{array}{l}\text { Proptosis, diplopia, } \\
\text { ptosis }\end{array}$ & L & \\
\hline 4 & Loo $(1994)^{12}$ & 71 & $\mathrm{~F}$ & Pain, diminished vision & $\mathrm{R}$ & \\
\hline 5 & Schwab $(1994)^{13}$ & 19 & M & Proptosis & L & \\
\hline 6 & Tranfa $(1994)^{14}$ & 85 & M & $\begin{array}{l}\text { Proptosis, pain, dimin- } \\
\text { ished vision }\end{array}$ & $\mathrm{R}$ & \\
\hline 7 & Kami $(1994)^{15}$ & 60 & M & Proptosis, headache & L & \\
\hline 8 & Font $(1998)^{16}$ & 79 & $\mathrm{~F}$ & $\begin{array}{l}\text { Proptosis, pain, dimin- } \\
\text { ished vision }\end{array}$ & $\mathrm{R}$ & \\
\hline 9 & Scolyer (1999) ${ }^{17}$ & 77 & M & Periorbital mass & $\mathrm{R}$ & FNAC \\
\hline 10 & $\operatorname{Kim}(2000)^{18}$ & 56 & $\mathrm{~F}$ & $\begin{array}{l}\text { Displaced eyeball } \\
\text { (orbital mass near } \\
\text { lower eyelid) }\end{array}$ & L & \\
\hline 11 & Chen $(2003)^{19}$ & 69 & M & Proptosis, diplopia & $\mathrm{R}$ & \\
\hline 12 & Gupta $(2005)^{5}$ & 45 & M & Proptosis & L & \\
\hline 13 & Oida $(2006)^{20}$ & 72 & M & Diplopia & L & \\
\hline 14 & $\begin{array}{l}\text { Machado-Netto } \\
(2006)^{21}\end{array}$ & 57 & M & Proptosis & $\mathrm{R}$ & \\
\hline 15 & $\begin{array}{l}\text { Hirunwiwatkul } \\
(2008)^{22}\end{array}$ & 74 & $\mathrm{~F}$ & $\begin{array}{l}\text { Proptosis with orbital } \\
\text { apex syndrome }\end{array}$ & $\mathrm{R}$ & \\
\hline 16 & Pittc $(2008) 23$ & 61 & $\mathrm{~F}$ & Painful proptosis & L & Necropsy \\
\hline 17 & ( 2 cases) & 47 & $M$ & $\begin{array}{l}\text { Proptosis, temporal } \\
\text { swelling }\end{array}$ & L & Necropsy \\
\hline 18 & Fonseca $(2008)^{24}$ & 57 & $M$ & Painful proptosis & $\mathrm{R}$ & \\
\hline 19 & Kolarević (2011) ${ }^{25}$ & 70 & $M$ & Painful proptosis & $\mathrm{R}$ & \\
\hline
\end{tabular}


Myint, Thant and Thazin

\begin{tabular}{|c|c|c|c|c|c|c|}
\hline & Authors & $\begin{array}{l}\text { Age } \\
\text { (years) }\end{array}$ & Sex & Presenting features & Laterality & Remark \\
\hline 20 & $\begin{array}{l}\text { Mustapha } \\
(2011)^{26}\end{array}$ & 25 & M & Painful proptosis & $\mathrm{R}$ & FNAC \\
\hline 21 & $\begin{array}{l}\text { Guerriero } \\
(2011)^{27}\end{array}$ & 45 & M & Proptosis & L & \\
\hline 22 & Jiang $(2012)^{27}$ & 44 & M & Proptosis, diplopia & Both & \\
\hline 23 & Piccirillo $(2013)^{29}$ & 66 & M & Mass at medial canthus & L & \\
\hline 24 & \multirow{6}{*}{$\begin{array}{l}\text { Eldesouky } \\
(2013)^{6} \\
(6 \text { cases })\end{array}$} & 62 & M & Painful proptosis & L & \\
\hline 25 & & 70 & M & Painful proptosis & L & \\
\hline 26 & & 55 & M & Proptosis & $\mathrm{R}$ & \\
\hline 27 & & 65 & M & $\begin{array}{l}\text { Painful proptosis, } \\
\text { redness, lacrimation }\end{array}$ & L & \\
\hline 27 & & 47 & M & Painful proptosis & L & \\
\hline 29 & & 62 & M & ptosis & $\mathrm{R}$ & \\
\hline 30 & Chen $(2014)^{30}$ & 56 & M & $\begin{array}{l}\text { Epiphora with pulsatile } \\
\text { mass in right lacrimal } \\
\text { gland }\end{array}$ & $\mathrm{R}$ & \\
\hline 31 & Chen $(2015)^{31}$ & 43 & M & Proptosis, headache & L & \\
\hline 32 & Kader $(2018)^{32}$ & 60 & M & $\begin{array}{l}\text { Swelling at lateral } \\
\text { aspect of the eye, } \\
\text { blurred vision, pain, } \\
\text { watery discharge }\end{array}$ & L & \\
\hline 33 & Present case & 57 & M & $\begin{array}{l}\text { Bilateral proptosis, soft } \\
\text { tissue mass }\end{array}$ & Both & \\
\hline
\end{tabular}

F: female; FNAC: fine needle aspiration cytology; L: left; M: male; R: right

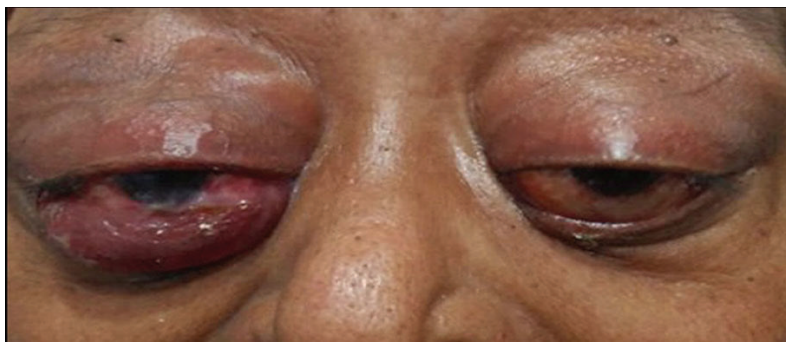

Fig. 1. Bilateral proptosis with exposure keratopathy in RE. 
without exposure keratopathy. Pupils were reactive. The intraocular pressure was $18 \mathrm{mmHg}$ in $\mathrm{BE}$. Other anterior and posterior segment examinations were unremarkable in $\mathrm{BE}$.

Orbital computerized tomography (CT) scan showed soft tissue masses in the superotemporal quadrants of both orbits, measuring $3.0 \times 3.7 \mathrm{~cm}$ in the right and $2.3 \times 2.6 \mathrm{~cm}$ in the left. There were lytic bone lesions in both lateral walls and right frontal bone (Fig. 2).

We performed percutaneous incisional biopsy from the right orbital mass through a direct sub-brow approach. The lesion was friable and bled severely upon touch. Multiple small pieces were sent for a histopathologic examination. The section revealed fibrous tissue infiltrated by metastatic deposits composed of large polygonal-shaped epithelial cells arranged in a trabeculo-sinusoidal pattern. The cells contained eosinophilic cytoplasm and hyperchromatic nuclei (Fig. 3). The features were consistent with metastatic HCC. We did not perform immunohistochemical studies as there were limited facilities.
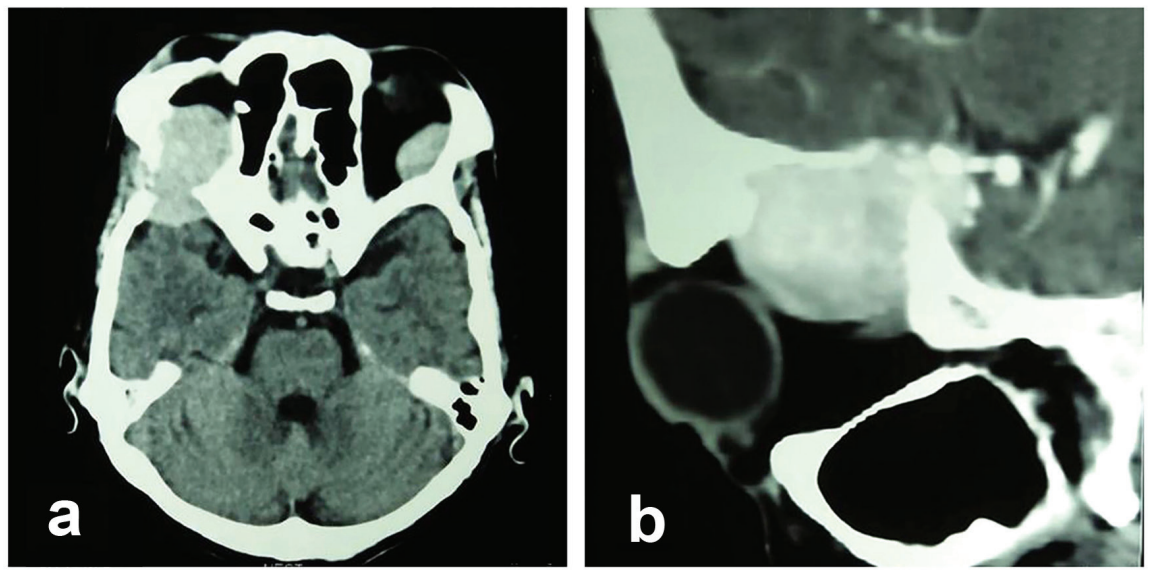

Fig. 2. CT scan. (a) Axial scan showed extraconal soft tissue masses in both orbits. (b) Right frontal bone destruction.
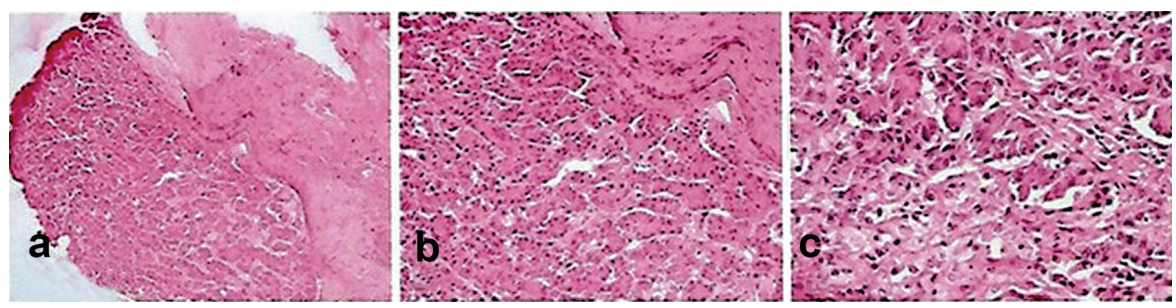

Fig. 3. Histopathological report. (a) 4x: Metastatic tumor deposit. (b) 20x: Tumor cells arranged in trabeculo-sinusoidal pattern. (c) 40x: Features of anaplasia. 
We referred the patient for further assessment. Abdominal ultrasound confirmed multifocal HCC with underlying cirrhosis. We planned for further investigations such as hepatitis serology, alfa-fetoprotein, and abdomen $\mathrm{CT}$, but he refused to proceed with investigations and treatment. Informed consent was taken from the patient to share and publish these findings.

\section{Discussion}

Orbital metastasis, more so as a bilateral involvement, is a rare phenomenon. When it occurs, ocular manifestations can be the primary presentations without prior history of systemic cancers in $15-19 \%$ of cases. ${ }^{1,4}$ However, in orbital metastasis, particularly from HCC, it can be as high as $50 \%{ }^{5,6}$ Ocular signs from orbital metastasis secondary to HCC often present earlier than that of primary cancer. ${ }^{7}$

Approximately $80-90 \%$ of patients with HCC have chronic liver disease and cirrhosis caused by alcoholic liver disease and chronic infection with the hepatitis $B$ and $C$ viruses. ${ }^{2}$ In low- and middle-income countries, chronic hepatitis B and C infection is attributed to over $90 \%$ of $\mathrm{HCC}^{3}$ Our patient did not provide a history of alcohol drinking, and we could not identify the hepatitis serology status as he refused to proceed further. It is pertinent to note that exposure to aflatoxin is a significant risk factor in Southeast Asia, as the humidity in the region favors the contamination of traditional food by the fungus. ${ }^{2,3}$

The histopathological diagnosis of orbital metastasis from HCC is primarily confirmed by the presence of large polygonal cells, trabecular pattern, and endothelial cuffing. Renal cell carcinoma may present with a similar histological feature. The use of carcinoembryonic antigen and alfa-fetoprotein can differentiate HCC from renal cell carcinoma. Immunohistochemical (IHC) markers are useful to diagnose the primary cancers in undifferentiated types of orbital metastasis. In HCC, several markers are available; arginase-1 and hepatocyte paraffin antigen (Hep Par 1) yielded the highest sensitivity for well-differentiated type, whereas combined use of arginase- 1 and glypican-3 has $100 \%$ sensitivity for poorly differentiated type. ${ }^{8}$

Biopsy-proven orbital metastasis from HCC was first reported in 1980 by Lubin and colleagues. ${ }^{9}$ Since then, a few cases have been reported in the literature. We performed a literature search and identified a total of 32 biopsy-confirmed orbital metastasis from HCC to date. ${ }^{5,6,9-32}$ It is common in males and aging adults. Most cases presented with proptosis and all cases except one were unilateral. It affects both eyes equally with no significant preference. In one series of 100 patients with orbital metastasis, only $4 \%$ had bilateral involvement, and the primary cancers were one each from breast, prostate, cutaneous melanoma, and choroidal melanoma. ${ }^{1}$ There was one report of bilateral orbital metastasis involving multiple extraocular muscles from HCC. ${ }^{28}$ To our best knowledge, our patient is the first 
case presenting with bilateral orbital soft tissue masses from metastatic HCC. Based on imaging findings, many authors reported that HCC metastasizing to the orbits is associated with adjacent bone changes such as bone destruction, bone erosion, and notching. 5,6,22,31 Similarly, our case had lytic changes noted in both lateral walls and right frontal bones adjacent to the tumor masses.

There are multi-disciplinary treatment modalities for orbital metastasis. External beam radiation is the mainstay of treatment. Surgery, adjuvant chemotherapy, immunotherapy, or hormonal therapy can be considered in selected cases. Patients with HCC metastasizing to the orbit have a relatively poor prognosis. ${ }^{5}$ Generally, survival is limited to 1.5 years after orbital manifestations irrespective of primary neoplasms. ${ }^{4}$

There are several learning points in this case report. Firstly, it was the first case of biopsy-proven bilateral orbital metastasis involving soft tissue of the orbit. Secondly, HCC may present with bilateral orbital metastasis. Thirdly, this report highlights that orbital metastatic tumors may present as an initial manifestation of undiagnosed systemic cancer and should be considered an important differential diagnosis in cases with bilateral proptosis. Furthermore, we reviewed the previously published data and presented the clinical presentations of orbital hepatocellular metastasis. However, we were unable to analyze the IHC markers for this patient nor the follow-up as the patient refused further management.

\section{Conclusion}

Orbital metastatic tumors may present as an initial manifestation of undiagnosed systemic cancer. Although bilateral orbital metastasis is extremely rare, it should be considered when diagnosing patients with bilateral proptosis, and orbital biopsy is crucial for histopathological diagnosis.

\section{References}

1. Shields JA, Shields CL, Brotman HK, Carvalho C, Perez N, Eagle RC. Cancer Metastatic to the Orbit: the 2000 Robert M. Curtis Lecture. Ophthal Plast Reconstr Surg. 2001;17:346-354.

2. Zhu RX, Seto WK, Lai CL, Yuen MF. Epidemiology of hepatocellular carcinoma in the Asia-Pacific region. Gut and Liver. 2016;1:332-339.

3. Torre LA, Siegel RL, Ward EM, Jemal A. Global cancer incidence and mortality rates and trends an update. Cancer Epidemiol Biomarkers Prev. 2016;25:16-27.

4. Valenzuela AA, Archibald CW, Fleming B, et al. Orbital metastasis: clinical features, management and outcome. Orbit. 2009;28(2-3):153-159.

5. Gupta R, Honovar SG, Vemuganti GK. Orbital metastasis from hepatocellular carcinoma. Surv Ophthalmol. 2005;50:485-489

6. Eldesouky MA, Elbakary MA, Shalaby OE, Shareef MM. Orbital metastasis from hepatocellular carcinoma: report of 6 cases. Ophthal Plast Reconstr Surg. 2014; 30(4):e78-81.

7. Amemiya T, Hayashida H, Dake Y. Metastatic orbital tumors in Japan: a review of literature. Ophthalmic Epidemiol. 2002;9:35-47. 
8. Nguyen T, Philips D, Jain D, et al. Comparison of 5 immunohistochemical markers of hepatocellular differentiation for the diagnosis of hepatocellular carcinoma. Arch Pathol Lab Med. 2015;139:1028-1034.

9. Lubin JR, Grove AS, Zarkov ZN, Albert DM. Hepatoma metastatic to the orbit. Am J Ophthalmol 1980;89:268-273.

10. Zubler MA, Rivera R, Lane M. Hepatoma presenting as a retro-orbital metastasis. Cancer. 1981;48:1883-1885.

11. Wakisaka S, Tashiro M, Nakano S, Kita T, Kisanuki H, Kinoshita K. Intracranial and orbital metastasis of hepatocellular carcinoma: report of two cases. Neurosurgery. 1990;26(5):863-866.

12. Loo KT, Tsui WMS, Chung KH, Ho LC, Tang SK, Tse CH. Hepatocellular carcinoma metastasizing to the brain and orbit: report of three cases. Pathology. 1994;26(2):119-122.

13. Schwab L, Doshi H, Shields JA, Kagame K, Chana H. Hepatocellular carcinoma metastatic to the orbit in an African patient. Ophthalmic Surg. 1994;25(2):105-106.

14. Tranfa F, Cennamoa G, Rosa N, Rosa GD, Boscaino A, Bonavolonta G. An unusual orbital lesion: hepatoma metastatic to the orbit. Ophthalmologica. 1994;208:329-332.

15. Kami H, Wada M, Matsuura J, Araya S. Case of hepatocellular carcinoma with an orbital metastasis as the initial symptom [in Japanese]. Nippon Naika Gakkai Zasshi 1994;3:622-624.

16. Font RL, Maturi RK, Small RG, Garcias-Rojas M. Hepatocellular carcinoma metastatic to orbit. Arch Ophthalmol. 1998;1 16:942-945.

17. Scoyler RA, Painter DM, Harper CG, Lee CS. Hepatocellular carcinoma metastasizing to the orbit diagnosed by fine needle aspiration cytology. Pathology. 1999;31:350-353.

18. Kim IT, Na SC, Jung BY. Hepatocellular carcinoma metastatic to the orbit. Korean J Ophthalmol. 2000;14:97-102.

19. Chen PH, Po HL, Lin YJ, Hseuh IH, Huang JK. Painful ophthalmoplegia as the initial manifestation of hepatocellular carcinoma: A case report and literature review. Acta Neurol Taiwan. 2003;12:93-96.

20. Oida Y, Ohtani Y, Dowaki S, et al. Hepatocellular carcinoma metastatic to the orbit: a case report. Tokai J Exp Clin Med. 2006;31(1):7-10.

21. Machado-Netto MC, Lacerda EC, Heinke T,Maia DC, Lowen MS, Saad ED. Massive orbital metastasis of hepatocellular carcinoma. Clinics (Sao Paulo). 2006;61:359-362. DOI: 10.1590/ S1807-59322006000400015

22. Hirunwiwatkul P, Tirakunwichcha S, Meesuaypong P, Shuangshoti S. Orbital metastasis of hepatocellular carcinoma. J Neuroophthalmol. 2008;28:47-50.

23. Pitts J, Chang CH, Mavrikakis I, Shaikh A, Rootman J. Hepatocellular carcinoma presenting as orbital bone metastasis. Ophthal Plast Reconstr Surg. 2008;24:477-479. DOI: 10.1097/ IOP.0b013e31818c9558.

24. Fonseca Júnior NL, Frizon L, Paves L, Wolosker AM, Manso PG. An unusual orbital metastatic lesion: the only finding in a case of hepatocellular carcinoma: case report. Arq Bras Oftalmol. 2008;71:865-867.

25. Kolarević $D$, Tomasević $Z$, Boricić I, et al: Metastasis of hepatocellular carcinoma presented as a tumor of the maxillary sinus and retrobulbar tumor. Vojnosanit Pregl. 2011;68:359-362.

26. Mustapha SK, Madachi DA. Orbital metastasis of hepatocellular carcinoma: a case report. West Afr J Med. 2011;30:305-307.

27. Guerriero S, Infante G, Giancipoli E, et al. Hepatocellular carcinoma metastasis to the orbit in a coinfected HIV+ HBV + patient previously treated with orthotopic liver transplantation: a case report. Case Rep Ophthalmol Med. 2011: 2011;Article ID 549270, 4 pages.

28. Jiang H, Wang Z, Xian J, Ai L. Bilateral multiple extraocular muscle metastasis from hepatocellular carcinoma. Acta Radiol Short Rep. 2012;1:1. DOI: 10.1258/arsr.2011.110002.

29. Piccirillo M, Granata V, Albino V, et al. Can hepatocellular carcinoma (HCC) produce unconventional metastasis? Four cases of extrahepatic HCC. Tumori. 2013; 99:e19-e23. 
30. Chen $\mathrm{H}$, Li J, Wang L, et al. Hepatocellular carcinoma metastasis to lacrimal gland: a case report. Oncology Letters. 2014;8:911-913. DOI: 10.3892/ol.2014.2191.

31. Chen CY, Zhong JH, Liu JL. Retrobulbar metastasis and intracranial invasion from postoperative hepatocellular carcinoma: a case report and review of the literature. Oncology Letters. 2015;9:721-726. DOI: 10.3892/ol.2014.2733

32. Kader NA, Abraham RM, Sathi PP. Unusual metastases of hepatocellular carcinoma: 2 cases. OGH Reports. 2018;7(2):109-110. DOI: 10.5530/ogh.2018.7.2.26 